\title{
State and Mafia, Differences and Similarities
}

\author{
Vincenzo Alfano \\ Università degli Studi di Napoli "Federico II” \\ Napoli, Italia \\ e-mail: vincenzo.alfano@unina.it
}

\begin{abstract}
:
The purpose of this article is to investigate about the differences and, if any, the similarities among the modern State and the mafia criminal organizations. In particular, starting from their definitions, I will try to find the differences between State and mafia, to then focus on the operational aspects of the functioning of these two organizations, with specific reference to the effect/impact that both these human constructs have on citizens' existences, and especially on citizen's economic lives. All this in order to understand whether it is possible to identify an objective difference - beside morals - between taxation by the modern State and extortion by criminal organizations. With this of course I do not want to argue that the mafia is in any way justifiable or absolvable, nor that it is better than the State. However, I want to investigate whether there is a real, logical reason why the State should be considered by the citizens more desirable than the criminal organizations oppressing Southern Italy, from a strictly logical point of view and not from the point of view of ethics and morality. Keywords: state, mafia.
\end{abstract}

\section{State $\neq$ mafia?}

I intend to begin this study with an analysis of some definitions of State, and a verification of the applicability of the same definitions to mafia-type criminal organizations. The first one I consider is the definition of Norberto Bobbio, according to whom:

The definition of the State that continually recurs is that the State is the holder of the monopoly of legitimate force, such as it is necessary because the majority of citizens is not virtuous but vicious. That's because the State needs strength and this is my conception of politics. [...] The reason why there are States, including republics, is to curb vicious citizens, who are the vast majority [1, p. 8].

This definition incorporates and expands a well known idea by Max Weber, according to whom the State is "a community of people in which the administrative apparatus successfully upholds the claim to the monopoly of the legitimate use of physical force within a given territory."

Why can the Camorra, the 'Ndrangheta, the Sacra Corona Unita or Cosa Nostra, the Southern Italy's powerful mafia organizations (referred from now on as 'mafia' without distinctions), not be considered States for the purposes of the above definitions? Essentially for the 
following three reasons: because these criminal organizations do not have a monopoly on force, because the force they use is not legitimate, and because the goals they pursue are not virtuous.

Let us begin right from this point: it is my own opinion, but I hope (and it seems) that's an opinion wide spread into the academy and literature ${ }^{1}$, that nothing is, by its own nature, virtuous; indeed, vice and virtue are tightly linked to the historical and cultural context in which they are considered. One could easily bring up, for example (making use of a motivation unfortunately quite common in Southern Italy), how it is considered virtuous by the mafia and their affiliates and supporters to force citizens to pay a fee for the maintenance of prisoners' families or widows of criminals. These in fact consider a virtuous act to contribute to the maintenance of women and children who, as a consequence of losing their husbands and fathers, struggle to make a living. Or again, it could be considered virtuous to extort money out of a company that has won a construction contract, to recover the funds that allow a criminal organization to maintain itself, and therefore its control and protection on the territory. I imagine that, just like me, some of the readers will not consider these examples virtuous: those I ask to understand that, in the same way and with exactly the same logic, many people - including me - would argue that there is just as little virtue in using force to enforce some of the objectives pursued by some modern States, such as conscription, monopoly on gambling, alcohol and tobacco, and of course wars. Also, I do not think there might be any doubts on defining Nazi Germany and Soviet Russia as States, and on how far from virtue they have strayed with their atrocities and purposes; at least from a historical perspective, therefore, even the biggest State-supporter must admit that State has not always been synonymous of virtue.

As for the monopoly of force, it can be easily shown that a criminal organization will never have a monopoly, as it will operate in a nation-State. But the argument can be reversed: nor the State could achieve monopoly, because of the existence of an organization criminal inside. It is therefore necessary to speak not of monopoly of force as an abstract ideal, but of monopoly of legitimate force. But who or what determines the legitimacy of the use of force? Different States have different limits on the use of force, and different centuries have seen very different ideas about which it is the border to legitimate the use of force. This fact suggests that there is no objective boundary between legitimate and illegitimate.

But even so, someone could still argue that while the number of cases in which the use of force by the State is permissible is published and ascertainable, the use of force by criminal organizations is more arbitrary. However, it is easy to see how, over time, the circumstances in which the State is permitted to use force change, in order to adapt to the goals pursued: once again, just think of the concept of lawful use of force three hundred years ago or today; therefore, this publication is not carved in stone and changes regularly. What makes it legitimate? In addition, as a further counter-argument, I doubt that anyone would consider legitimate the use of force on my part if I simply public announce (and publish!) that I will use violence against anyone will walk dressed in red in my surroundings! On the other hand, some criminal organizations have traditions alive and well articulated that guide their actions. This is a kind of "living constitution" that makes more or less predictable the use of force by them. Does this in the same way and for the same reasons we used to legitimate the States' use of the force makes it less odious or legitimate? I don't think so.

In conclusion, it seems that rest no option but that it's the State itself, tautologically, to consider its own use of force as legitimate: the word 'legitimate' has the same root of legis, and in its original sense means 'permitted by law': as stated, the law written by the State itself. Therefore, the State absolves itself, judging its own use of force as the only legitimate! And I have no doubt that for any organization to use the force by its own is just as legitimate! And that, given the 
opportunity, it would consider it's use of the force the only legitimate, and self-define itself as a State.

For other scholars of political science, the State is defined as the original, because its power comes only from itself and not by any higher entity. With this definition it is argued that the State is not subject to third parts, and is, therefore, independent and sovereign in a defined scope: it is organized as hierarchically structures for the best exercise of power. Again, it is easy to see a tautology in this definition. The State is not subject to other parts simply because it imposes subordination to all other entities that exist and insist on the territory in which it exercises its influence, and declares illegal all those who did not subordinate themselves. Also any mafia organization might claim, on the portion of land it occupies, its independence and sovereignty: certainly it does not pay taxes to an entity it recognizes as superordinate, and indeed demands that other entities, such as citizens or commercial activities of various kinds, operating on 'its' territory, should recognize their sovereignty and super-ordination. And it certainly does not believe that its powers are derived from the higher-level entity!

Another definition of State is tempted by Charles Tilly, which defines the State as [19]:

An organization that controls the population occupying a given territory is a State in so far as:

- it differs from other organizations that operate on the same territory;

- is autonomous;

- is centralized;

- each of its component parts is formally coordinated with each other.

Again, it can be seen to fall within the definition provided mafia criminal organizations. In fact, there is no doubt that these differ from other organizations working in the area: no one has difficulty distinguishing between the mafia and a cultural association, or a football club. The mafia organizations are autonomous, since, as we have already seen, certainly not derive their own power by the State; and they are equally certainly centralized, although various criminal organizations have varying degrees of territorial autonomy, as well as different States have different forms and levels of federalism; and still are composed of parts coordinated with one another, that's the reason why it's called “organized” crime. So even by the Tilly's definition, it is not possible to distinguish between the State and the mafia. Among other things, the American political scientist has also defined the State not only as an organization that provides security from external and internal threats in exchange for tax revenues (as the well known contract perspective), but also as an organization that represents a fundamental threat to the safety of its citizens should protect. Ultimately, the State provides protection for Tilly mainly by himself [17]! It is not difficult to see in this a parallel with the criminal organizations of southern Italy.

But is it really possible to distinguish between the State and mafia? We are looking for the answer by analysing the definition of State of another great thinker, Thomas Hobbes :

The State represents the instance unitary and sovereign neutralization of social and religious conflicts through the exercise of summa potestas, expressed through the abstract form and universality of the law which is legitimate under the mandate of authorization of individuals, in which there is the mechanism of political representation; citizens are in fact in the pre-policy which is defined as the state of 
nature and the sovereign plays a 'representative' uniting in itself the 'dispersed multitude’ [8].

At the first glance, it may seem very difficult to fall back to any form of organized crime in this definition. But I invite you to analyse the definition more carefully: for Hobbes the characteristic elements of the State seem to be primarily a function of unitarian, sovereign neutralization of social and religious conflict. Well, this is the function that, much of the State, in many parts of the country the mafia takes, for the mafia it is important to be recognized not only by the citizens as a guarantor of peace and stability, but also as a unique, effective authority to turn to for smooth social conflicts. The role of the mafia as pacifying religious conflicts is not, in fact, predominantly, in particular if we consider pacification between different religions (but on the other hand, this case is inapplicable to several States, especially those theocratic but not only). However, if we consider how religious conflicts interfere with religious beliefs of an organization to ensure that they are consistent with the social ones (e.g. the lawmaking function in the field of civil and religious marriage, ora of religious and civil holidays, etc.), well in this case the role of the mafia in some areas of Italy is perfectly comparable to that of the State. Just think of the threats made by mobsters to push men to marry those women they had gotten pregnant, as to 'not dishonour them', or more generally to the sacredness recognized the role of the church, and how the mafia seeks supports and take prestige from this.

Another charactheristic Hobbes consider is the summa potestas. It is unfortunately true that in some areas this influence is exercised by the mafia, and not by the State. But, for Hobbes, the summa potestas shall be expressed in the form of abstract and universal law. This is certainly not the form in which the mafia expresses its summa potestas. However, once again, we are facing the dilemma I expressed previously: is it just a matter of publishing and publicizing the rules? Because if the mafia acts according to patterns and principles, known or knowable in some way, why these should have less 'force of law' to those expressed by a State? And even these principles have an abstract and universal form! The laws are not but the codifications of habits and ancient customs. When the mafia demands that all commercial activities contribute to its 'cause' by giving a 'donation', what's this if not the applying of an abstract and universal principle? How is it different from taxation? Another controversial issue could be the following: the legitimation under the mandate of authorization of individuals, in which there is political representation, which for Hobbes is the unification of a multitude of instances missing. Surely the mafia is not entitled by a popular vote. However, it is authorized and considered authoritative by many citizens who live in certain areas of the Italian peninsula. In addition, if we consider the political representation as a unification of several instances in society as a criterion for the definition of a State, we could not consider a State a large part of African dictatorships, most of the States in the Middle East, and perhaps (stressing the concept) even any State that uses a majority law to elect Parliament, as this is undoubtedly detrimental to the representation of part of the scattered instances. So we have to consider in a more abstract way this Hobbesianly step. If we define the State as an organization empowered by the will of a vast majority of the population that inhabits it, and bringing together the various demands of society, well, in that case we can re-enter in the definition the criminal organizations in Southern Italy. Too many gangs, in fact, in their territories are entitled to a vast popular support, certainly higher than what the legitimate State enjoys in those places, and these are formed by parties who are carriers of several instances dispersed in society (the so-called godparents, after all, could be considered local leaders, and holders of the needs of the district that 'govern', against the 'central government' mafia). 
For Carl Schmitt [11], [12], [13], the State is the decisive political entity, because to it belongs the ius belli: it alone can determine the enemy, can promote war and require its members the ultimate sacrifice. Once again, however, we must admit that we face a tautological definition. The ius belli, in fact, is self attributed by the State. Furthermore, in light of recent developments in terrorism, the question is whether Schmitt would not return on its definition of State: is Al Qaeda a State? And what about other terrorist organizations? The season of bombs that there was in Italy between 19992 and 1993, was it a war? All questions to which it is difficult to respond in a negative way by using the definition of the State of Schmitt as a basis. For the German thinker, the primary function of State is not expressed in waging war or in controlling the private lives of citizens, but in establishing order and security. Once again, we face also one of the functions of organized crime: to establish order and security within the territory. So is still not easy, not even taking up the definition of the German, distinguish between the State and the mafia.

For Douglass North, "a State is an organization with a comparative advantage in violence, extending over a geographic area whose boundaries are determined by its power to tax residents" [10].

This definition is very interesting, since it defines the State, or rather its borders, in the light of the ability of taxing. With this in mind, at a first glance the mafia could not be considered a State. However, when analysing the definition more carefully, the mafia has undoubtedly, in certain areas of Italy, a comparative advantage in violence, and mainly finances its activities in three ways: asking for money to citizens living in a given territory, claimed as their own (the so-called 'pizzo'); taking resources from other citizens through theft and robbery; trading and managing other economic activities, legal and illegal. With reference to the first source of supply of money from the mafia, how can it be said that in certain areas of Italy, the residents are not 'taxed' by the mafia? Again, the only difference between the 'pizzo' and taxes, can be found in the legitimacy of the act. But, as we have shown, it is a tautology, since is the State considers itself as legitimate, by its own laws, its own violence and its taxation, and no other. Still on the subject of legitimacy, it could be said that the State is legitimate because it is considered as such by the majority of citizens who insist on a given territory. However, even taking this path, the argument does not resist very soon, in fact we should consider that in certain areas of Italy, the mafia is considered more legitimate and more desirable than the Italian State by resident citizens, and that in other parts of Italy (i.e. in Veneto, where the secessionist demands are becoming stronger, but also in the Aosta Valley or in the provinces of Trento and Bolzano) where the mafia is not so strong, the legitimacy of the Italian State is widely questioned. What is it that makes it legitimate, beyond the tautological issue already addressed in the law?

Still, for some the State is recognized as such by the international community of States. Although interesting, and oozing Realpolitik from every pore, once again we are facing a tautological definition and not very useful ontologically. It also raises several new problems: how were born the first States? From those are them been recognized, if they are 'equal' members of a community? In which case there is not such a thing as a State? When is it not recognized by another $^{2}$ ? Or if it is not recognized by the majority of the other States ${ }^{3}$ ? Or is there a different ratio, such as being not recognized by any of the members of the international community ${ }^{4}$ ? And then, of whom is truly established the international community? Only by members of the UN? So, this way to define the State probably raises more problems than it solves.

In the light of what we saw, therefore, it must be said that a definition of the State that is able at the same time to exclude the mafia, and to include the vast majority of the members of the international community of States, cannot be found. 


\section{Tribute $\neq$ pizzo?}

Once ascertained the impossibility of distinguishing, by means of a comprehensive definition and not by tautological reasoning, between the State and the mafia, I intend to continue this study by trying to define the tributes, to see whether, at least in this, is detectable an own specificity that distinguishes the compulsory levy from the State from the operating criminal organizations, such as the 'pizzo', the so-called 'protection money'. Indeed, if it's not possible to differentiate the State by the mafia, maybe it's the case to being able to differentiate the taxes that it requests from the 'pizzo' required by the mafia. For the purposes of this paragraph, by tribute I mean all taxes and levies imposed as a mandatory requirements (or monopolistically ${ }^{5}$ ) from one State to its own citizens. The tribute, whose etymology comes from the collection that, in ancient Rome, was carried out for tribes $^{6}$, is defined by Treccani encyclopedia ${ }^{7}$ as:

generic name of any cash benefit payable by citizens to the State and other public bodies, namely general and special taxes, erarial and local surcharges, taxes and mandatory contributions. [...] The notion of tribute today include: taxes, fees, contributions and fiscal monopolies.

Let us leave aside taxes, which are defined as an amount paid by the citizen in exchange for a service offered by the State ${ }^{8}$, and that even for the Italian Constitutional Court ${ }^{9}$ as opposed to the taxes do not refer to Article 53 of Constitution, which reads "everyone shall contribute to public expenditure because of their ability to pay [...].”

At least for the Italian case, therefore, the taxes, the expression of the exercise of taxing powers of a sovereign entity par excellence, are due to contribute to public expenditure. Scholars distinguish three functions of the tribute: acquisitive, which is to finance the expenditure required to maintain the bureaucracy; distribution, that is to change the distribution of wealth between taxpayers; and promotional material, which consists in encouraging or discouraging certain conduct. The 'pizzo', however, is defined as a form of extortion practiced by the mafia which consists in requiring the payment of a part of the earnings or a fixed amount of income, by operators of commercial and business, in exchange for a supposed and ill-defined 'protection' of the activity. Aside from the subject that requires it, because as we have seen it is not easy to define the State excluding the mafia from the definition, we can see how the pizzo has the same characteristics of taxes.

The pizzo in fact has certainly acquisitive function: it finance the expenditure required to maintain the organization that organizes the withdrawal. It also has, at least namely, a distribution function (as indeed any type of withdrawal): in fact it changes the distribution of wealth between taxpayers (if this redistribution is desirable or not, is an entirely different matter: on the other hand, if there was a distribution objectively and universally desirable all States should do the same tax policy, seeing that these are the most diverse, or we do not consider taxes those imposed by state agencies States that apply to certain tax policies, or also those obtained with the pizzo are considered forms of redistribution. Someone could argue that the tax policy of a State is a deliberately distribution while the action of the pizzo has distribution only as a secondary effect and not pursued: however considering the population affiliated with the mafia, and close to these at various levels, certainly the action of pizzo involves a redistribution of income from groups of citizens farther from the mafia in favour of those most faithful to this, and it's a pursued effect); and 
the pizzo is also promotional: not all activities are in fact 'taxed' by the mafia in the same way, the demand for pizzo is variable depending on the area and the types of activities; therefore these criminal organizations create places and activities where there is an incentive to invest and other where is not. In addition, the will of several Italian entrepreneurs of not to invest in the south of Rome, demonstrates alone the promotional character of the pizzo.

So what is the difference between State tributes and pizzo ${ }^{10}$ ? Just as it seems to be impossible to define the State without including the definition mafia criminal organizations, does not seem possible to find a feature not found in pizzo in tributes.

\section{Devaluation}

In addition to taxes, the only alternative for the State to raise money is by printing it. This inevitably leads to inflation. Milton Friedman put forward the famous statement: "Inflation is always and everywhere a monetary phenomenon” [5].

Fortunately, the mafia does not have the ability to print money, but continuing in the parallel carried out so far we can say that the equivalent of inflation to mafia is theft and robbery. If in fact the pizzo is closely linked to productive activities, and therefore predictable and 'manageable' by the entrepreneur, but thefts and robberies are occasional and unpredictable. In exactly the same way of robbery, inflation devalue private saving, for a monetary policy imposed by the State. However, unlike the previous cases, in this case there is a difference with the thefts and robberies perpetrated by the mafia: in fact hardly a criminal activity of this kind will be able to be as damaging as inflation. There is no need to quote the exceptional cases of 1980 in Italy, with an inflation rate of $21.2 \%{ }^{11}$, or the hyperinflation of Zimbabwe ${ }^{12}$. In 2011 inflation in Italy was 2.8\% (see [7]). Considering that the average income in 2010 was of 19,250 euro ${ }^{13}$, inflation has taken away from every single citizen 539 Euros on average. Much more than any criminal organization may have stolen by dint of robberies!

\section{Final thoughts}

If it is not possible, without the use of personal (and therefore by definition controversial and questionable) ethical principles, to distinguish between the State and the mafia, what makes State taxes less odious and unwanted than the pizzo "protection"?

If, as we seen, there is no possible difference between State and mafia, the use of the force by both to force citizen to give them money, it's just a form of robbery, and nothing else. And the natural and wide spread revolt, disgust and repugnance of honest citizens for criminal organizations which steal money from them to pursue their own, obscure, goals, should be equally reserved to the State.

Why then do we insist to grant to an entity that has repeatedly been shown to not be able to fulfil the tasks which aims, even when these are considered desirable by the individual, and not to be efficient, to govern our lives?

As already mentioned in the introduction, I want to close this work by pointing out once again that I do not intend in any way with this study to accredit or justify the odious gangs that harass and haunt Italy and the world, but instead would like to propose a more serious reflection on the role and legitimacy that the State should have in our lives. 


\section{References}

1. Bobbio, N., Dialogo intorno alla repubblica. Laterza: Roma-Bari, 2001.

2. Clark, W. M., Golder, R., Golder, S., Principi di scienza politica. McGrawHill: Milano, 2011.

3. Conticello, F., L'isola che c'è. La Sicilia che si ribella al pizzo. Round Robin editrice: Roma, 2008.

4. De Fina, G., No al pizzo. Imprenditori siciliani in trincea. Thor editrice: Palermo, 2008.

5. Friedman, M., A Monetary History of the United States 1867-1960. Princeton University Press: Princeton, 1963.

6. Grasso, T., Varano, A., U'Pizzu. L'Italia del racket e dell'usura. Baldini Castoldi Dalai: Milano, 2002.

7. Hanke, S. H., New Hyperinflation Index (HHIZ) puts Zimbabwe Inflation at 89.7 sextillion percent. The Cato Institute, 2008.

8. Hobbes, Thomas, Leviatano. 1651.

9. La Spina, A., (a cura di), I costi dell'illegalità. Mafia ed estorsioni in Sicilia. Il Mulino: Bologna, 2008.

10. North, D., Istituzioni, cambiamento istituzionale, evoluzione dell'economia. Il Mulino: Bologna, 2007.

11. Schmitt, C., Dottrina della costituzione (a cura di Caracciolo). Giuffré: Roma, 1984.

12. Schmitt, C., Il custode della costituzione (a cura di Caracciolo). Giuffré: Roma, 1981.

13. Hofmann, H., Legittimità contro legalità. La filosofia politica di Carl Schmitt. Edizioni Scientifiche italiane: Napoli, 1999.

14. Tilly, C., Conflitto e democrazia in Europa. Bruno Mondadori: Milano, 2007.

15. Tilly, C., Credit and Blame. Princeton University Press: Princeton, 2008.

16. Tilly, C., Democracy. Cambridge University Press: Cambridge, 2007.

17. Tilly, C., Identities, Boundaries, and Social Ties. Paradigm Publishers: Boulder. 2005.

18. Tilly, C., L'oro e la spada. Ponte alle Grazie: Milano, 1993.

19. Tilly, C., La formazione degli stati nazionali in Europa occidentale. Il Mulino: Bologna, 1984.

20. Tilly, C., Le rivoluzioni europee 1492-1992. Laterza: Bari, 2002.

21. Tilly, C., Perché? La logica nascosta delle nostre azioni quotidiane. Rizzoli: Milano, 2007.

22. Tilly, C., Regimes and Repertoires, University of Chicago Press: Chigago, 2006.

23. Tilly, C., Wood, L., Social Movements, 1768-2008, Paradigm Publishers: Boulder, 2004.

24. Vecchio, A., Ricette di Legalità. Noventacento Edizioni: Milano, 2009.

\section{Notes}

1. For instance, a good example of this is Franz Boas' idea of cultural relativism, an axiomatic principle established in the first decades of the $20^{\text {th }}$ century by his students. Boas articulated the ideas in 1887, writing “...civilization is not something absolute, but/is relative, and/our ideas and conceptions are true only so far as our civilization goes” [Franz Boas, Museums of Ethnology and their classification, Science 9:229, 1887].

2. That's the case of Armenia, a UN member who's not recognized by the Pakistan; of Cyprus, whom is not recognized by Turkey and Northern Cyprus; of Israel, not recognized by 32 different UN members; of North Korea, not recognized by South Korea and Japan; of South Korea, not recognized by North Korea; and even of China, that even as a permanent member of the Security Council, is not recognized by 22 UN members (which recognizes Taiwan).

3. Actually, Palestine is recognized by $138 \mathrm{UN}$ members, and is part of the General Assembly as observer. Is it a State? And what's about Taiwan, that's recognized by 23 UN members, and that is a former permanent member of the Security Council?

4. That's the case of Somaliland.

5. I.E. the tobacco in Italy: being a State monopoly, and so being impossible to other players than the State to operate in that sector, in fact any italian smoker tax himself on a voluntary way.

6. http://www.treccani.it/enciclopedia/tributo/

7. Ibidem.

8. As, for example, the italian TaRSU, Tassa per lo smaltimento dei Rifiuti Solidi Urbani, which stands for Urban 
Solid Waste Managment Tax, paid (at least on a theorical plan!) by the citizens to have a public garbage disposal. 9. Italian Constitutional Court, sentences number 30/1964, 23/1968, 91/1972.

10. By the way, if there is no difference between pizzo and charges, and these are an expression of the exercise of taxing powers of a sovereign body, it adds another element that suggests difficulty distinguishing between State and mafia too, since these organizations criminals prove to be sovereign entities.

11. Indice nazionale dei prezzi al consumo (NIC con tabacchi).

12. In which it seems that the annual inflation rate is equal to 89.7 trillion of billions percentage points! See [7].

13. Dichiarazioni dei redditi IRPEF 2011. 